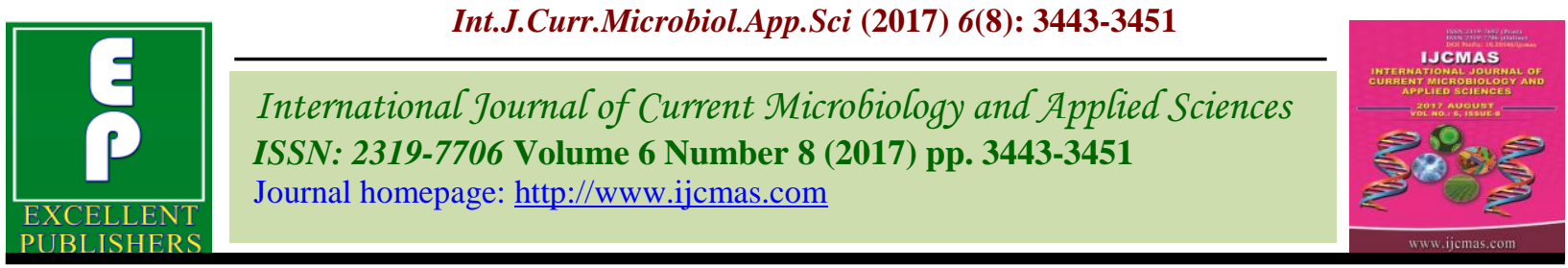

Original Research Article https://doi.org/10.20546/ijcmas.2017.608.413

\title{
Heterosis and Combining Ability Studies for Quality Traits in Soybean [Glycine max (L.) Merrill]
}

\author{
Indu Rialch ${ }^{*}$, Jai Dev ${ }^{2}$ and Bhupender Kumar ${ }^{3}$ \\ ${ }^{1}$ Department of Plant Breeding and Genetics, Punjab Agricultural University, \\ Ludhiana- 141004, India \\ ${ }^{2}$ Chaudhary Sarwan Kumar Himachal Pradesh Krishi Vishvavidyalaya, Palampur-176062, India \\ ${ }^{3}$ ICAR-Indian Institute of Maize Research, New Delhi- 110012, India \\ *Corresponding author
}

\section{A B S T R A C T}

\section{Keywords}

Soybean, Protein and oil quality,

GCA.

Article Info

Accepted:

27 June 2017

Available Online:

10 August 2017
Soybean occupies, as importance, the first place in the group of grain legumes due to its use in human nutrition, as a source of very good protein and oil quality, as herb and because it is a very good prior plant to the ground, leaving a reserve of 80 to $140 \mathrm{~kg} \mathrm{~N} / \mathrm{ha}$. Heterosis and combining ability studies were carried in 54 crosses derived from crossing of 18 soybean lines with 3 testers. Based on various estimates viz., mean performance, heterosis and combining ability the best soybean parents and crosses for quality traits were identified. Combining ability analyses indicated that Shivalik showing the largest general combining ability (GCA) effect for protein and oil contents was the best combiner, and identified several best cross combinations with high positive specific combining ability (SCA) effects. These crosses involved geographically diverse parents and at least one parent of high General Combining Ability (GCA) effects in combination of high $\mathrm{x}$ high, high $\mathrm{x}$ average and high $\mathrm{x}$ low. Therefore, these crosses could throw transgressive segregants in still advance generations. The results of present study suggested that heterosis coupled with high SCA effects might be considered as criteria for selecting crosses for further improvement with respect to quality traits.

\section{Introduction}

Soybean [Glycine max (L.) Merrill] is a wonderful crop gifted by the nature to mankind which is one of the richest sources of oil as well as protein. It belongs to the family Leguminosae and is a self-pollinated crop having chromosome number of $2 \mathrm{n}=40$. Soybean is one of the most important crops that have the potential to provide the world's increasing demand for food and forage. The spread of soybean from its native land of origin has been mainly due to its adaptability and predominant use as a food crop for human nutrition, as a protein source for animals, as a medicinal plant and lately as an industrial crop (Alghamdi, 2004). Soybean is the cheapest, richest and easiest source of best quality protein. Owing to multiplicity of uses as food and industrial products, soybean is called as "Wonder crop". Soybean seed contains about $20.5 \%$ carbohydrates, $20 \%$ oil with poly unsaturated fatty acids specially Omega 6 and Omega 3 fatty acid, 4.5\% minerals, $3.7 \%$ fibre, $8.1 \%$ water and $43.2 \%$ protein, its protein is complete and contains 
all the essential amino acids therefore from nutritional point of view it is known as "Miracle bean". It also contains a good amount of salts, vitamins and health promoting phyto-chemicals for human and livestock. Soybean is an environment friendly grain legume and its cultivation improves soil health because of its atmospheric nitrogen fixing ability and deep root system. Soybean is a dominant oil seed crop in the world trade accounting about $25 \%$ world's total oil and fats production. Soybean has become the major source of edible vegetable oil and high quality proteins for food and feed supplement all over the world. Demand for soybean is still raising day by day as it has become major oil seed and also serves as raw material for various industries. To develop elite and better nutritional quality varieties such cultivars a systematic approach has to be adopted. Protein and oil are polygenic characters and their improvement is basically based upon identification and selection of superior parents or lines, which can be effectively used for developing superior quality genotypes for breeding programme. Combining ability studies are regarded useful in assessing the relative nicking ability of parents, which on crossing would produce more desirable segregants and elucidate the nature and magnitude of gene action involved. The study becomes much more reliable if a good degree of correspondence is observed between various genetic estimates over filial generations. Further, extent of heterosis will have direct effect on breeding methodology in varietal improvement programmes. Therefore, keeping aforesaid considerations in view, present study was undertaken in soybean to evaluate, identification and selection of better nutritional quality genotypes.

\section{Materials and Methods}

The experimental materials comprised 18 fixed lines, three testers of soybean and their
54 triple test cross families. Two agronomically superior and diverse genotypes, Him soya and Hara soya $\left(\mathrm{P}_{1}\right.$ and $\mathrm{P}_{2}$ ) and their $\mathrm{F}_{1} \mathrm{~s}$ were used as testers ' $\mathrm{L}_{1}$ ', ' $\mathrm{L}_{2}$ ' and ' $\mathrm{L}_{3}$ ', respectively. Details of material used are given in Table 1 . The parents were selected on the basis of diverse pedigree, growth habit, geographical origin and adaptation. The fifty four $\mathrm{F}_{1}$ hybrids, 18 lines and 3 testers were grown in a completely randomized block design with three replications during kharif 2013. The experimental plot of each treatment consisted of one row of $2 \mathrm{~m}$ length. Row to row and plant to plant distances were maintained at 50 and $20 \mathrm{cms}$, respectively.

Protein and oil content in seed samples of each genotype for each replication was estimated with the help of Infratec ${ }^{\text {TM}} 1241$ grain analyzer which uses near-infrared transmittance technology to test multiple parameters, viz., moisture, protein, oil, starch etc. in a broad range of grain and oilseed commodities (Sudar et al., 2007). Different types of heterosis viz., heterosis over mid parent, heterobeltiosis over better parent and economic heterosis over standard check were estimated using mean values. Analysis of line $\mathrm{x}$ tester data for combining ability was done according to Kempthorne (1957) and Arunachalam (1974).

\section{Results and Discussion}

Analysis of variance was carried out for lines, tester, their crosses and that revealed highly significant differences for all the lines and crosses indicating sufficient variation in the material for both protein and oil content. However, mean squares due to testers were significant for only protein content. The study for mean and range revealed that among parents there was great variability in the lines than testers for both the characters. It was reflected that the hybrids superior in F1 
involved both or at least one parent of high per se performance.

For protein content, the highest positive heterosis over both mid parent and better parent was recorded for H-330 x Him Soya. Out of 36 hybrids, 25 exhibited positive heterosis over mid parent and 22 exhibited positive heterosis over better parent. Out of these crosses exhibiting positive heterosis, there were 20 and 13 crosses exhibiting significant heterosis over mid and better parent, respectively.

Gadag and Upadhyaya (1995) and Sabbouh et al., (1998) also observed significant positive heterosis for protein content. The range of heterosis over mid parent was from -6.06 to 8.65 per cent and over better parent it was from -11.15 to 8.58 per cent (Table 2).

In case of oil content, the range of heterosis over mid parent was from -17.89 to 12.44 per cent and over better parent it was from -24.07 to 11.12 per cent for this trait. Cross $\mathrm{H}-330 \mathrm{x}$ Him Soya exhibited the highest significant heterosis over mid parent and better parent. There were 10 hybrids which showed positive heterosis over mid parent and five hybrids indicated positive heterosis over better parent. Four crosses, viz., H-330 x Him Soya, P6-1 x Him Soya, P169-3 x Him Soya and H-330 x Hara Soya over mid parent and only one cross H-330 x Him Soya over better parent had significant heterosis. Similar results have been reported by Chen (1983), Wehrmann et al., (1987), Fahmi et al., (1999) and several other workers.

In autogamous crops like soybean, combining ability provides required information about the nature and magnitude of genetic variation along with nicking ability of genotypes. Over and above, the study become much more precise and reliable if the relative combining ability is analyzed in F1, F2, and F3 generations so as to obtained a good degree of correspondence between these estimates which will help in identifying superior parents and crosses that could be effectively utilized in breeding progamme. Such study may also reflect the possibility of obtaining rare favourable combinations of characters in segregating generations.

Analysis of variance for combining ability for both the quality traits indicated that variance due to crosses, lines and line $\mathrm{x}$ tester interaction were significant for protein and oil content. Significance of lines and testers indicated higher contribution towards general combining ability, while for lines $\mathrm{x}$ tester interaction towards specific combining ability for both the characters. Predominance of estimated component of Specific Combining Ability (SCA) variance over General Combining Ability (GCA) indicated importance of non-additive genetic effects for protein and oil content. Contribution of lines was higher for protein content, whereas higher contribution due to interaction between line and tester was for oil content.

On the basis of heterosis, it can be concluded that heterosis was displayed for almost all the characters. Seed yield is the sum total of contribution made by individual component and hence a complex character itself. The breeder has to simplify complex situation to breed for high yield by handling number of related traits simultaneously. A good number of crosses showed the presence of desirable heterotic response for the different characters over the standard cultivars.

Among the parents lines Shivalik, SL-795, P2-2, P6-1 and H-330 recorded positive significant GCA effects for protein content. While for oil content Shivalik, PS-1466, SL679, P13-4 and PS-1469 could be considered superior as these exhibited high GCA effects (Table 3). 
Table.1 Soybean lines used to generate hybrids in this study

\begin{tabular}{clll}
\hline S. No. & Lines & S. No. & Lines \\
\hline 1 & SL-682 & 12 & P2-2 \\
2 & P6-1 & 13 & H-330 \\
3 & SL-679 & 14 & PS-1469 \\
4 & P9-2-2 & 15 & VLS-59 \\
5 & DS1213 & 16 & JS-335 \\
6 & PK-472 & 17 & P169-3 \\
7 & Hardee & 18 & P13-4 \\
8 & Bragg & & Testers \\
9 & SL-795 & 1 & Him Soya $\left(\mathrm{L}_{1}\right)$ \\
10 & Shivalik & 2 & Hara Soya $\left(\mathrm{L}_{2}\right)$ \\
11 & PS-1466 & 3 & Hara Soya $x$ Him Soya $\left(\mathrm{L}_{3}\right)$ \\
\hline
\end{tabular}

Table.2 Estimation of heterosis (MP), heterobeltiosis (BP), economic heterosis (EP) and in breeding depression for protein and oil content in soybean

\begin{tabular}{|c|c|c|c|c|c|c|}
\hline \multirow[t]{2}{*}{ Cross } & \multicolumn{3}{|c|}{ Seed protein content $(\%)$} & \multicolumn{3}{|c|}{ Seed oil content $(\%)$} \\
\hline & MP & $\mathbf{B P}$ & EP & MP & BP & EP \\
\hline P9-2-2 x Him Soya & $7.13 *$ & $6.67 *$ & $7.61 *$ & -2.47 & $-4.65 *$ & $-4.65^{*}$ \\
\hline P9-2-2 x Hara Soya & 0.93 & -0.65 & 0.23 & $-5.24 *$ & $-13.18 *$ & -0.36 \\
\hline PS-1466 x Him Soya & $-6.06^{*}$ & $-10.57 *$ & -1.06 & 1.66 & -0.42 & -0.42 \\
\hline PS-1466 x Hara Soya & $-5.65^{*}$ & $-11.15^{*}$ & -1.70 & $-4.64 *$ & $-12.47 *$ & 0.46 \\
\hline P6-1 x Him Soya & $-2.38 *$ & $-4.48 *$ & -0.19 & $7.83^{*}$ & 2.81 & 2.81 \\
\hline P6-1 x Hara Soya & -0.35 & $-3.58 *$ & 0.76 & 1.03 & $-9.58 *$ & $3.78 *$ \\
\hline PK-472 x Him Soya & 0.00 & -0.90 & 0.92 & 2.29 & 1.75 & 1.75 \\
\hline PK-472 x Hara Soya & $5.29 *$ & $3.17 *$ & $5.07 *$ & $-11.30 *$ & $-17.42 *$ & $-5.22 *$ \\
\hline VLS-59 x Him Soya & $3.20 *$ & $2.89 *$ & $2.89 *$ & -1.07 & -2.79 & -2.79 \\
\hline VLS-59 x Hara Soya & $3.40 *$ & $2.53 *$ & $1.92 *$ & $-8.74 *$ & $-15.99 *$ & $-3.59 *$ \\
\hline P13-4 x Him Soya & 0.65 & 0.45 & 0.84 & 0.64 & -1.61 & -1.61 \\
\hline P13-4 x Hara Soya & $3.17 *$ & 1.81 & $2.20 *$ & $-5.80 *$ & $-13.70 *$ & -0.95 \\
\hline PS-1469 x Him Soya & $3.58 *$ & $3.53 *$ & $3.63 *$ & 1.27 & 1.12 & 1.12 \\
\hline PS-1469 x Hara Soya & $3.67 *$ & $2.44 *$ & $2.54^{*}$ & $-4.39 *$ & $-10.67 *$ & 2.52 \\
\hline DS-1213 x Him Soya & $2.01 *$ & 0.98 & $3.06^{*}$ & $-3.83 *$ & $-6.90 *$ & -0.55 \\
\hline DS-1213 x Hara Soya & -0.29 & $-2.40 *$ & -0.39 & $-7.75 *$ & $-10.95^{*}$ & 2.20 \\
\hline SL-679 x Him Soya & $5.23 *$ & $4.14 *$ & $6.33 *$ & -1.11 & $-5.09 *$ & $-5.09 *$ \\
\hline SL-679 x Hara Soya & $7.77 *$ & $5.47 *$ & $7.69 *$ & $-15.68 *$ & $-24.07 *$ & $-12.85^{*}$ \\
\hline SL-682 x Him Soya & $2.32 *$ & 0.29 & 4. $42 *$ & $-3.32 *$ & $-4.45^{*}$ & -2.16 \\
\hline SL-682 x Hara Soya & $3.84 *$ & 0.65 & $4.80 *$ & $-8.97 *$ & $-13.88 *$ & -1.16 \\
\hline H-330 x Him Soya & $8.65 *$ & $8.58 *$ & $8.58 *$ & $12.44 *$ & $11.12 *$ & $13.80 *$ \\
\hline H-330 x Hara Soya & $7.65^{*}$ & $6.49 *$ & $6.36^{*}$ & $4.06^{*}$ & -1.54 & $13.00 *$ \\
\hline P169-3 x Him Soya & $1.96 *$ & 1.25 & 1.25 & $-2.78 *$ & -2.94 & -2.94 \\
\hline P169-3 x Hara Soya & 1.51 & 1.06 & -0.35 & $6.50 *$ & -0.51 & $14.18^{*}$ \\
\hline P2-2 x Him Soya & $3.68 *$ & $3.35 *$ & $4.02 *$ & $-7.64 *$ & $-9.39 *$ & $-5.83 *$ \\
\hline P2-2 x Hara Soya & $3.70 *$ & $2.20^{*}$ & $2.86^{*}$ & $-15.18 *$ & $-19.19 *$ & $-7.25^{*}$ \\
\hline Shivalik x Him Soya & -1.58 & $-2.59 *$ & -0.55 & $-2.63 *$ & $-5.18 *$ & 0.06 \\
\hline Shivalik x Hara Soya & $2.40 *$ & $1.53^{*}$ & $1.92 *$ & $-5.14 *$ & $-8.96^{*}$ & $4.48 *$ \\
\hline Hardee x Him Soya & -0.51 & $-1.88 *$ & 0.91 & -0.01 & -1.95 & 2.01 \\
\hline Hardee x Hara Soya & 1.43 & -1.09 & 1.72 & $-8.48 *$ & $-12.75^{*}$ & 0.13 \\
\hline JS-335 x Him Soya & 0.32 & -0.56 & 1.22 & -0.97 & -1.84 & -1.84 \\
\hline JS-335 x Hara Soya & $2.61 *$ & 0.57 & $2.37 *$ & $-10.15^{*}$ & $-16.62 *$ & $-4.31 *$ \\
\hline SL-795 x Him Soya & $224 *$ & 1.22 & 1.22 & $-7.48 *$ & $-12.81 *$ & -1.44 \\
\hline SL-795 x Hara Soya & $4.45^{*}$ & $4.30^{*}$ & $2.22 *$ & $-17.89 *$ & $-18.51 *$ & $-6.47 *$ \\
\hline Bragg x Him Soya & $-3.39 *$ & $-6.20 *$ & -0.41 & 0.36 & 0.06 & 0.66 \\
\hline Bragg x Hara Soya & $-2.18^{*}$ & $-6.07 *$ & -0.27 & -1.80 & $-7.86 *$ & $5.75 *$ \\
\hline
\end{tabular}

* Significant at $\mathrm{P} \leq 0.05$ 
Table.3 General Combining Ability (GCA) effects for quality traits in soybean

\begin{tabular}{|c|c|c|}
\hline \multirow[b]{2}{*}{ Genotype } & \multirow[b]{2}{*}{ Seed protein content $(\%)$} & \multirow[b]{2}{*}{ Seed oil content $(\%)$} \\
\hline & & \\
\hline P6-1 & $0.62 *$ & $-0.43 *$ \\
\hline SL-682 & $-1.36^{*}$ & 0.02 \\
\hline SL-679 & $-0.74 *$ & $0.59 *$ \\
\hline P9-2-2 & 0.27 & $-0.29 *$ \\
\hline DS-1213 & 0.05 & $-0.55 *$ \\
\hline PK-472 & -0.27 & -0.21 \\
\hline Hardee & 0.31 & $0.33^{*}$ \\
\hline Bragg & -0.35 & 0.16 \\
\hline SL-795 & $1.77 *$ & $-1.56^{*}$ \\
\hline P2-2 & $0.88^{*}$ & $-0.28 *$ \\
\hline Shivalik & $1.95^{*}$ & $2.36^{*}$ \\
\hline PS-1466 & $-0.67 *$ & $1.00 *$ \\
\hline $\mathrm{H}-330$ & $0.44 *$ & $-1.13 *$ \\
\hline PS-1469 & $-1.19 *$ & $0.41 *$ \\
\hline VLS-59 & -0.35 & 0.20 \\
\hline JS-335 & -0.17 & $-0.53 *$ \\
\hline P169-3 & -0.20 & $-0.68 *$ \\
\hline P13-4 & $-0.97 *$ & $0.57 *$ \\
\hline $\mathrm{SE}(\mathrm{gi}) \pm$ & 0.18 & 0.13 \\
\hline $\mathrm{SE}(g i-g j) \pm$ & 0.25 & 0.18 \\
\hline \multicolumn{3}{|l|}{ Testers } \\
\hline Him Soya & 0.08 & -0.06 \\
\hline Hara Soya & -0.08 & 0.06 \\
\hline $\mathrm{SE}(\mathrm{gi}) \pm$ & 0.06 & 0.04 \\
\hline $\mathrm{SE}($ gi-gk $) \pm$ & 0.08 & 0.06 \\
\hline
\end{tabular}

* Significant at $\mathrm{P} \leq 0.05$ 
Table.4 Specific Combining Ability (SPA) effects for quality traits in soybean

\begin{tabular}{|c|c|c|c|c|c|c|c|}
\hline S.N. & Crosses & Protein content $(\%)$ & Oil content (\%) & S.N. & Crosses & Protein content $(\%)$ & Oil content $(\%)$ \\
\hline 1 & P9-2-2 x Him Soya & $1.29 *$ & -0.32 & 20 & SL-682 x Hara Soya & 0.15 & 0.03 \\
\hline 2 & P9-2-2 x Hara Soya & $-1.29 *$ & 0.32 & 21 & H-330 x Him Soya & 0.33 & 0.13 \\
\hline 3 & PS1466 x Him Soya & 0.04 & -0.02 & 22 & H-330 x Hara Soya & -0.33 & -0.13 \\
\hline 4 & PS1466 x Hara Soya & -0.04 & 0.02 & 23 & P169-3 x Him Soya & 0.21 & $-1.45^{*}$ \\
\hline 5 & P6-1 x Him Soya & -0.26 & -0.03 & 24 & P169-3 x Hara Soya & -0.21 & $1.45^{*}$ \\
\hline 6 & P6-1 x Hara Soya & 0.26 & 0.03 & 25 & P2-2 x Him Soya & 0.13 & 0.18 \\
\hline 7 & PK-472 x Him Soya & $0.86^{*}$ & $0.67 *$ & 26 & P2-2 x Hara Soya & -0.13 & -0.18 \\
\hline 8 & PK-472 x Hara Soya & $-0.86^{*}$ & $-0.67 *$ & 27 & Shivalik x Him Soya & -0.96 & -0.53 \\
\hline 9 & VLS-59 x Him Soya & 0.09 & 0.13 & 28 & Shivalik x Hara Soya & 0.96 & $0.53 *$ \\
\hline 10 & VLS-59 x Hara Soya & -0.09 & -0.13 & 29 & Hardee x Him Soya & -0.23 & 0.22 \\
\hline 11 & P13-4 x Him Soya & -0.34 & -0.002 & 30 & Hardee x Hara Soya & 0.23 & -0.22 \\
\hline 12 & P13-4 x Hara Soya & 0.34 & 0.002 & 31 & JS-335 x Him Soya & -0.29 & 0.27 \\
\hline 13 & PS1469 x Him Soya & 0.12 & -0.07 & 32 & JS-335 x Hara Soya & 0.29 & -0.27 \\
\hline 14 & PS1469 x Hara Soya & -0.12 & 0.07 & 33 & SL-795 x Him Soya & -0.27 & $0.49 *$ \\
\hline 15 & DS1213 x Him Soya & $0.56^{*}$ & -0.18 & 34 & SL-795 x Hara Soya & 0.27 & $-0.49 *$ \\
\hline 16 & DS1213 x Hara Soya & $-0.56^{*}$ & 0.18 & 35 & Bragg x Him Soya & -0.11 & $-0.39 *$ \\
\hline 17 & SL-679 x Him Soya & -0.34 & $0.74 *$ & 36 & Bragg x Hara Soya & 0.11 & $0.39 *$ \\
\hline 18 & SL-679 x Hara Soya & 0.34 & $-0.74 *$ & & $\operatorname{SE}(\mathrm{Sij}) \pm$ & 0.25 & 0.18 \\
\hline 19 & SL-682 x Him Soya & -0.15 & -0.03 & & $\mathrm{SE}(\mathrm{Sij}-\mathrm{Skl}) \pm$ & 0.36 & 0.26 \\
\hline
\end{tabular}

* Significant at $\mathrm{P} \leq 0.05$ 
Table.5 Best parents and crosses selected on the basis of their per se performance, GCA effects, SCA effects and heterotic response for protein and oil content in soybean

\begin{tabular}{lll}
\hline Characters & Protein content & Oil content \\
\hline Best parents per se & Shivalik, SL-795, P2-2, P6-1 and H-330 & Shivalik, PS-1466, SL-679, P13-4 and PS- \\
& & 1469 \\
Best crosses per se & H-330 x Him Soya, SL-679 x Hara Soya, & P169-3 x Him Soya, H-330 x Him Soya, \\
& P9-2-2 x Him Soya, H-330 x Hara Soya, & H-330 x Hara Soya, Bragg x Hara Soya, \\
& SL-679 x Him Soya & P6-1 x Hara Soya \\
Best heterotic Crosses & H-330 x Him Soya, SL-679 x Hara Soya, & P169-3 x Him Soya, H-330 x Him Soya, \\
& P9-2-2 x Him Soya, Shivalik x Hara Soya & H-330 x Hara Soya, Bragg x Hara Soya, \\
& H-330 x Hara Soya, SL-679 x Him Soya & Shivalik x Hara Soya \\
Best GCA parents & Shivalik, SL-795, P2-2, P6-1 and H-330 & Shivalik, PS-1466, SL-679, P13-4 and PS- \\
& & 1469 \\
Best SCA Crosses & P9-2-2 x Him Soya, PK 472 x Him Soya, & P169-3 x Hara Soya, SL-679 x Him Soya, \\
& Shivalik x Hara Soya and DS-1213 x Him & PK 472 x Him Soya, Shivalik x Hara Soya, \\
& Soya & SL-795 x Him Soya and Bragg x Hara \\
& & Soya \\
\hline
\end{tabular}

The per se performance of most of the parent was moderate to high for protein and oil content. Among the hybrids, positive significant SCA effects for protein content were exhibited by P9-2-2 x Him Soya, PK472 x Hara Soya and DS-1213 x Him Soya. On the other hand many crosses viz., P169-3 x Hara Soya, SL-679 x Him Soya, PK 472 x Him Soya, SL-795 x Him Soya and Bragg x Hara Soya showed significantly high SCA effects for oil content (Table 4). Among these hybrids most of them had high per se and involving good general combiner parents, hence, could be used effectively in quality improvement of soybean. Therefore on the basis of combining ability effects, crosse PK $472 \times$ Him Soya appeared promising for both protein and oil content. While P9-2-2 x Him Soya and P169-3 x Hara Soya were good specific combiner for protein and oil content, respectively. Similar to present findings Mc Kendry et al., (1985) and Gadag et al., (1999) also reported importance of non-additive gene effects for protein content. On the contrary, Zhu et al., (1994) and Sabbouh et al., (1998) noted significant GCA and additive effects for protein content in soybean. In case of oil content, as per present study Sharma et al., (1997) and Sabbouh et al., (1998) recorded partial dominance and non-additive gene action and Raut et al., (2000) reported dominance gene effects in 2 crosses for seed oil content in soybean. Contrary to this, significant additive gene action was reported by Zhu et al., (1994) for oil content.

Based on various estimates viz., mean performance, heterosis and combining ability the best soybean parents and crosses for quality traits were identified (Table 5). For both protein and oil content, high heterosis and positive SCA effects were recorded in cross Shivalik x Hara Soya and could be further exploited. This cross involved geographically diverse parents and at least one parent of high GCA effects in combination of high $\mathrm{x}$ high, high $\mathrm{x}$ average and high $\mathrm{x}$ low. Majority of soybean breeding work is based on pedigree method, which exploits the fixable additive type of gene effects. However, this alone may be inadequate in view of the large non-additive component for both quality traits. Further, high heterosis for oil and protein along with positive SCA effects was observed in these crosses, which might be due to dominance or epistasis. Although heterosis breeding makes maximal use of the non-additive genetic effects appears to be difficult for improving soybean in view of the non-availability of 
mass pollination systems needed for hybrid seed production. Accordingly, the feasible alternative is to consider simultaneous exploitation of both additive and non-additive gene action by adopting recurrent selection procedures. Under similar situation Harer and Deshmukh (1991) recommended biparental mating in soybean followed by recurrent selection. Since crossing is tedious in soybean, genetic male sterility and single seed or single pod descent method could be employed to facilitate recurrent selection schemes (Wilcox, 1998). Therefore, these crosses could throw transgressive segregants in still advance generations. Further, the results of present study suggested that heterosis coupled with high SCA effects might be considered as criteria for selecting cross for further improvement with respect to quality traits.

To conclude, combining ability mean squares estimated revealed that both the quality traits displayed preponderance of non-additive gene effects. Often the unfavorable association between protein and yield generally met with are due to tight linkages, which could be broken by raising a large population. In the present study H-330 x Him Soya revealed superiority for protein content, oil content as well as yield might be considered a new favorable combination resulted due to breaking of tight linkages. Through the use of recurrent selection suggested that such negative relationship may be caused by linkage and improvements can be made for such traits by enforcing simultaneous selection in large segregation population.

\section{References}

Alghamdi, S.S., 2004. Yield stability of some soybean genotypes across diverse environments. Pakistan Journal of Biological Sciences, 7(12): 2109-2114. Arunachalam, V., 1974. The fallacy behind the use of a modified line $\mathrm{x}$ tester design. Indian J. Genet. 34: 280-287.

Chen, H.H. 1987. Dallel analysis of the genetic regulation of protein and oil content in soybean. Sci. Agri. Simi. 20: 32-38.

Fahmi, A.L., Eissa, R.A., Nawar, A.A., Habeeb, M.H. and Zayed, E.M. 1999. Genetic performance of seed quality characters of five soybean [Glycine max (L.) Merrill] varieties and their diallel crosses. Menoufiya Journal of Agricutlural Research 24: 999-1015

Gadag, R.N., and Upadhyaya, H.D. 1995. Heterosis in soybean [Glycine max (L.) Merrill]. Indian J. Genet. 55: 308-314.

Gadag, R.N., Upadhyaya, H.D. and Goud, J.V. 1999. Genetic analysis of yield, protein, oil and other related traits in soybean. Indian J. Genet. 59: 487-492.

Harer, P.N., and Deshmukh, R.B. 1991. Components of genetic variation in soybean [Glycine max (L.) Merrill]. J. Oilseeds Res. 8: 220-225.

Kempthorne, 1957. An Introduction to Genetical Statistics. Wiley, New York.

Mc Kendry, A.I., McVetty, P.B.E. and Voldeng, H.D.1985. Inheritance of seed protein and seed oil content in early maturing soybean. Canadian J. Genet. Cytol. 27: 603-607.

Raut, V.M., Taware, S.P. and Halvankar, G.B. 2000. Gene effects for some quantitative characters in soybean [Glycine max (L.) Merrill] crosses. Indian J. Agric. Sci. 70: 334-335.

Sabbouh, M.V., Edurrds, L.H. and Khim, K.R.1998. Heterosis and Combining ability for protein and oil concentration in the seed of soybean [Glycine max (L.) Merrill]. SABRAO J. Breed.Genet. 30: 7-17.

Sharma, S.R., Phul, P.S., Raheja, R.K. and Ahuja, K.L. 1997. Nature of gene effects for fatty acid in soybean. Crop Improv. 24:273-274. 
Sudar, R., Jurković Z, Galonja M, Turk I and Arambašić M. 2007. Application of Near Infrared Transmission for the Determination of Ash in Wheat Flour. Agriculturae Conspectus Scientificus 72: 233-238.

Wehrmann, V.K., Fehr, W.R., Cianzio, S.R. and Cavins, J.F. 1987. Transfer of high seed protein to high-yielding soybean cultivars. Crop Sci., 27: 927-931.

Wilcox, J.R. 1998. Increasing seed protein in soybean with 8 cycles of recurrent selection. Crop Sci., 38: 1536-1540.

Zhu, H.D., Yu, J.Z., Zhou, K.J., Li, H. and Yu, M.1994. Studies on soybean breeding for high content of both oil and protein. Acta Agronomica Sinica. 20: 614-620.

\section{How to cite this article:}

Indu Rialch, Jai Dev and Bhupender Kumar. 2017. Heterosis and Combining Ability Studies for Quality Traits in Soybean [Glycine max (L.) Merrill]. Int.J.Curr.Microbiol.App.Sci. 6(8): 3443-3451. doi: https://doi.org/10.20546/ijcmas.2017.608.413 